\title{
A Values-Engaged Approach to Cultivating Civic Professionalism in Graduate Education
}

\author{
Elizabeth K. Goodhue \\ University of California, Los Angeles
}

\begin{abstract}
This article employs the emerging theoretical framework of values-engaged assessment to develop a narrative analyzing recent efforts to expand and formalize opportunities for graduate students to participate in community-engaged teaching and research at UCLA. After establishing the historical and institutional background for a new graduate seminar on engaged pedagogy and public scholarship, the article presents reflections from five graduate student contributors. The author's voice serves to weave these student stories into a larger conversation analyzing the opportunities and challenges involved in advancing engaged graduate education at large research universities. The research team's collaborative narrative demonstrates that engaged graduate students continue to face significant challenges; but our story also shows that when research universities begin to position graduate student civic professional development as central to the public mission of higher education, this shift in values creates new opportunities to reimagine what it means - and what it takes - for research universities to serve the public good in the twenty-first century.
\end{abstract}

As with many large research universities, the University of California, Los Angeles (UCLA) has a long history of integrating community engagement activities with academic credit-bearing courses and research programs for undergraduates. The majority of these initiatives are coordinated through a central hub, the UCLA Center for Community Learning. Although graduate students often have been involved in implementing community engagement initiatives at this campus and at peer institutions, the scholarship on civic engagement in higher education has largely ignored the experiences and goals of graduate students - and historically, research universities have rarely provided structured, formal support for graduate professional development in community-engaged pedagogy and public scholarship. ${ }^{1}$ Thankfully, however, there has been increasing nationwide interest in exploring how graduate student professional development in community engagement benefits all stakeholders in campus/community partnerships. This essay adds to the growing body of scholarship on communityengaged graduate education by employing the emerging theoretical framework of values-engaged assessment to develop a narrative analyzing recent efforts to expand and formalize opportunities for graduate students to participate in communityengaged teaching and research at UCLA.

Championed by Imagining America's Assessing the Practices of Public Scholarship (APPS) working group and by contributors to the thought pieces published by the Service-Learning and
Community Engagement (SLCE) Future Directions Project (Bandy et al., 2016; see also Bartha \& Nigro, 2013; Dolson, Figura, \& Gale, 2016), values-engaged assessment marks a renewed effort to respond to the challenges of "liv[ing] out commitments to democratic engagement in an academic culture and society often characterized by technocratic tendencies [and] neoliberal (marketdriven) imperatives" (Bandy et al., p. 96). ${ }^{2}$ Proponents of values-engaged assessment contend that groups engaged in campus/community partnership work can best respond to these pressures by developing and implementing models of program planning grounded in five core values: collaboration, reciprocity, generativity, rigor, and practicability (Bandy et al.; Bartha \& Nigro). As Bartha and Nigro explain, these values "borrow from multiple literatures and fields [but] centering them offers an intervention of sorts" (n.p.) - one that brings Imagining America's humanistic approach to engaged teaching and research to bear on the assessment of such work. Indeed, as the case studies published by the APPS working group demonstrate, values-engaged assessment offers researchers a "flexible and adaptable framework" for developing rich humanistic narratives that "inquire into qualities of relationships, the transformation of systems, and the empowerment of all partners over time" (Bartha \& Nigro, 2013, n.p.; Bandy et al., p. 97).

Engaged graduate education is ideally suited for this emerging mode of inquiry because graduate stu- 
dents occupy a contested position within the established power structures of the technocratic, neoliberal university - and an ambiguous position within prevailing narratives of engagement in higher education. At once recipients of university instruction and also sources of intellectual and instructional labor, graduate students often find that their values and concerns prove to be out of sync with those of the institutions that not only grant their degrees but also profit from their tuition dollars and labor. ${ }^{3}$ But the position of engaged graduate students is especially tenuous because the commitments and goals of such students have historically been undervalued not only by neoliberal and technocratic ideologies, but also by the work of academic civic engagement that purports to resist such trends. Values-engaged assessment is ideally positioned to respond to these disparities by centering the ethos of inclusion and giving engaged graduate students a voice in how campus/community partnerships are designed, implemented, and assessed.

This article charts the first stage in the UCLA Center for Community Learning's long-term efforts to integrate the development of graduate students as civic professionals into our center's work more intentionally - and into the public mission of the university more fully. The essay opens with an overview of recent trends in American graduate education at research universities, as well as an introduction to specific contexts at UCLA that made the timing ideal for launching a new seminar on engaged pedagogy and public scholarship for graduate students on our campus in the winter of 2017. In this section, a brief description of how the center involved graduate students in planning this new course helps to illustrate how values-engaged assessment aligns with asset-based models of community development through a shared "focus on process as well as product" and a shared commitment to "question[ing] whose perspectives should be included and what metrics best give voice to them" (Bandy et al., 2016, p. 97). After establishing this background, the article presents an assessment of our inaugural seminar and of engaged graduate education at UCLA more broadly through stories from five graduate students. My own voice appears throughout this section of the essay as well, but primarily serves to weave these five student voices into a larger conversation analyzing the opportunities and challenges involved in advancing engaged graduate education at large research universities. By foregrounding student voices in this way, the project builds on recent efforts to mobilize - and recognize - engaged graduate students as key agents in the work of social and institutional change (Gilvin, Roberts, \& Martin, 2012; Post,
Ward, Longo, \& Saltmarsh, 2016).

In keeping with the ethos of values-engaged assessment, these five graduate students - Jonathan Banfill, Vanessa Febo, Sarah Roth, Carrie Sanders, and Alexandra Verini - are not passive objects of a case study but instead active collaborators on a shared research project, and formal contributors to this article. ${ }^{4}$ These student leaders continue to play a crucial role in our center's ongoing efforts to develop a deeper understanding of the present state of engaged graduate education on our campus and in the wider landscape of American higher education, and they have been instrumental in shaping this essay's recommendations for the future of such work. Together, we have found that engaged graduate students at large research universities continue to face significant challenges accessing support for community-engaged teaching and research - both intellectually and financially. However, our self-assessment efforts also uncovered exciting intersections between our center's new practicum course and other emerging initiatives on our campus and at peer institutions. Together, these developments suggest that we are in the midst of a nascent but pronounced shift in academic culture that is opening up new opportunities for engaged graduate education. As research universities such as UCLA begin to position graduate student civic professional development as central to the public mission of higher education, this shift in values not only creates new opportunities for our most advanced students to put their personal commitments and academic training to work in the world, but also expands the prevailing sense of what it means - and what it takes - for research universities to serve the public good in the twenty-first century.

\section{Historical and Institutional Background}

While community engagement has a long and vibrant history in undergraduate education and in scholarly conversations about undergraduate education, scholars of community engagement have only recently turned their attention to the experiences and goals of graduate students (Applegate, 2002; Austin \& Barnes, 2005; Austin \& McDaniels, 2006; Doberneck, Brown, \& Allen, 2010; Eatman, 2012; Gilvin et al., 2012; Matthews, Karls, Doberneck, \& Springer, 2015; O'Meara, 2008; O'Meara \& Jaeger, 2006; Post et al., 2016; Stanton \& Wagner, 2010). As Stanton and Wagner observe, "many students experience the transition to graduate study as a withdrawal from public and community service that was a vital part of their undergraduate years" (p. 412). Stanton and Wagner argue this disparity in values is especially acute at research 
universities - and particularly for graduate students earning degrees in letters and science disciplines. Other scholars concur, noting that while graduate students earning professional degrees in fields such as engineering and medicine generally have at least some opportunities to engage in forms of applied research or in the delivery of discipline-related services as part of their degree programs, graduate students earning degrees in fields such as English, history, and chemistry often find that their disciplines undervalue public scholarship and offer few opportunities to collaborate with community partners as part of the graduate curriculum (O'Meara; O’Meara \& Jaeger; Stanton \& Wagner). Instead, graduate training in letters and science fields tends to prioritize preparing students to serve as what the Carnegie Initiative on the Doctorate terms "stewards of the discipline" (Golde, 2006, p. 3). This model frames graduate study as an apprenticeship to a "guild of stewards" responsible for generating new knowledge and conserving and transforming knowledge generated by others (Golde \& Dore, 2001, p. 14).

Crucially, although the intellectual labor of disciplinary stewardship could theoretically take place in any sector, the guild apprenticeship model of graduate education strongly implies that the ideal profession of graduate students, and especially for those earning doctorates, is that of their master teachers - university professors. The model thus assumes the site of students' postgraduate work will continue to be a college campus. Although there are some notable exceptions to this trend (for students entering the field of public history, for instance, and for those engaged in translational science research), this organizing assumption is generally strong, and it limits how and what students learn during graduate study as well as the futures they can envision for themselves after graduation. A 2001 Pew Charitable Trusts survey of doctoral students offers evidence of this limiting effect, finding that although "over half $(52.1 \%)$ of students are very interested in providing service to the community [. . . o]nly $13.8 \%$, however, reported any preparation by their programs for this role" (Golde \& Dore, 2001, p. 26). Moreover, while professional degree programs in fields such as education and public health are often more intentional about preparing students for community work, O'Meara (2016) cautions that faculty who lead such programs at research universities can still find themselves "embedded in systems of legitimacy [that] constrain the agency and recognition of engaged scholars" (p. 97) - and these systems can constrain students in such fields as well. ${ }^{5}$

Historically, research universities have been es- pecially prone to value what Boyer $(1990,1996)$ famously termed the "scholarship of discovery" over the "scholarship of engagement." This disparity produces an institutional culture in which tenured and tenure-track faculty are often unprepared and/ or unmotivated to support graduate students interested in community engagement - and those faculty members who do identify as engaged scholars often struggle to find institutional support for their own work, let alone that of students (Driscoll \& Lynton, 1999; Ellison \& Eatman, 2008; O'Meara, 2010, 2016; O'Meara \& Rice, 2005). Indeed, under the prevailing neoliberal paradigm, large research universities can be more likely to involve graduate students in applied research that is entrepreneurial in nature - as in the case of UCLA's Technology Fellows Program, which engages graduate students in the process of developing patentable technologies and other products - instead of projects grounded in the sorts of reciprocal partnerships with nonprofit organizations and government agencies that form the backbone of civically engaged undergraduate education. Faced with limited support for such values in the graduate curriculum, advanced students at research universities often find they must pursue community engagement activities on their own time, or by taking advantage of limited opportunities to support community-engaged instruction in the undergraduate curriculum.

Until very recently, graduate education at UCLA has mirrored to a large extent the trends outlined above. For example, graduate students at UCLA serve as teaching assistants for undergraduate service-learning lectures and seminars led by faculty, and under the guidance of the Center for Community Learning and academic departments, they also serve as lead instructors for lower-division service-learning courses in the writing curriculum and coordinate upper-division independent study internship courses. Graduate students also support academic engagement initiatives at UCLA by serving as research assistants for projects ranging from course design to assessment to partnership cultivation. However, despite this evidence of a vested interest in and commitment to community-engaged learning, graduate students have historically had few opportunities to participate in community engagement as part of their coursework at UCLA, particularly at the doctoral level.

At the Center for Community Learning, we are proud of our long history providing training and mentorship for graduate students employed by our center and other campus units, but we also recognize that this support has been limited in scale and lacking in the defined structure central to the success of our undergraduate programs (such as 
our signature civic engagement minor). This lack of formal graduate programming can be traced, in part, to an administrative decision to house the center within UCLA's Division of Undergraduate Education when that division was created approximately a decade ago. But as new leadership entered the center and the division, many of us came to see the lack of structured programming to support graduate students as inconsistent with the center's values and, in particular, out of step with our commitment to advancing democratic engagement and full participation both on and off campus (Saltmarsh, Hartley, \& Clayton 2009; Sturm, Eatman, Saltmarsh, \& Bush, 2011). In light of this recognition, we began leveraging staff meetings with the graduate students we employed in 2014-15 and 2015-16 as opportunities to explore what an expanded program of professional development for engaged graduate students might look like at UCLA. We also began collaborating with other groups on campus interested in related issues, such as an interdisciplinary graduate student working group focused on inclusive teaching and social justice pedagogy that formed in 2014-15.

These small-scale organizing efforts led to the center's first day-long summit on communityengaged teaching and public scholarship for graduate students, held in the fall of 2015, and co-facilitated by student leaders from the social justice working group. Inspired by similar institutes convened at peer institutions to explore best practices for engaged graduate education, this intensive workshop culminated in an opportunity for UCLA graduate students to share what they think graduate education for engaged, inclusive, actionoriented teaching and research should look like on our campus. ${ }^{6}$ While this discussion prompt spurred a wide-ranging conversation, attendees were in agreement on two primary recommendations: first, they wanted our campus to increase funding available to support engaged teaching and research for graduate students; and second, while they valued extracurricular workshops and other informal programming, attendees wanted to have their participation in engagement activities reflected on their transcripts through formal courses. The Center for Community Learning wholeheartedly endorsed both recommendations but had limited flexibility to address funding issues immediately - and so we decided to focus our efforts on developing a graduate course on best practices for community-engaged teaching and research.

Since UCLA has an established tradition of offering teaching practicum courses for graduate students in various disciplines, we hoped it would be a straightforward process to create a similar course under the Civic Engagement subject area that our center has used to offer undergraduate courses for nearly a decade - but this proved more complicated than we anticipated since the Division of Undergraduate Education had never offered graduate courses. After much debate, the decision was made to offer our practicum in partnership with UCLA's Graduate Division under a new subject area called Graduate Student Professional Development. We piloted our weekly two-hour seminar with nine students in the winter of 2017.

Similar to other teaching practica at UCLA, our seminar focused largely on pedagogy - in this case introducing graduate students to best practices for engaged teaching and to strategies for incorporating research with community partners into academic courses. While constraints of the quarter system and teaching practicum format prevented us from offering opportunities for students to collaborate with community partners on engaged research or service-learning projects in this seminar, all participants observed an undergraduate service-learning course and attended a panel discussion with some of the center's long-time community partners. These activities provided an impetus for the group to discuss the prospect of developing graduate-level opportunities for service-learning and engaged research in the future. The practicum course culminated with students designing their own syllabi for engaged courses, and included several shorter writing assignments that offered semi-structured opportunities for students to reflect on the current state of engaged graduate education at UCLA and share their vision for the future. These reflections inspired many of the stories shared in the following section of this article. A copy of the syllabus, including discussion topics and reflection prompts, can be viewed on the course website.

In some ways, our center's decision to begin expanding community-engaged graduate professional development at UCLA with a course focused largely on engaged pedagogy falls in line with dominant trends in the growing body of scholarship on community-engaged graduate education. Much of this work advocates framing community-engaged professional development for graduate students in terms of preparing the next generation of engaged faculty (Applegate, 2002; Austin \& Barnes, 2005; Austin \& McDaniels, 2006; Doberneck et al., 2010; Eatman, 2012; Matthews et al., 2015; O'Meara, 2008; O'Meara \& Jaeger, 2006). One of our center's aims in developing a practicum on engaged pedagogy at UCLA was, indeed, to create infrastructure to help graduate students to become more effective instructors on our campus, more competitive applicants on the academic job market, 
and more successful engaged faculty in the future if they choose to pursue such a career.

However, as the stories in the following section make abundantly clear, the graduate students who have sought to connect with our center over the years are interested in engaged teaching and research for a wide range of reasons above and beyond training for tenure-track jobs. Many care deeply about social justice work and either currently work in community settings (often on their own time) or did so prior to graduate study - and they are looking for professional development opportunities that respond to their diverse experiences, motivations, and goals. Observing similar complexity in the values of engaged graduate students in the University of Washington system, Bartha and Burgett (2014) caution against framing graduate professional development merely as training to compete in a cutthroat tenure-track job market. They argue that this approach "ignores students' motivations for entering into graduate programs in the first place" and disregards the degree to which many graduate students - and especially engaged graduate students - "have more complex commitments and view their relation to institutions of higher education more critically" (Bartha \& Burgett, p. 39). Pushing this point a step further, Gale (2012) urged engagement professionals to "put our driving commitments at the center" of our work and our professional development efforts (p. 325), arguing that this values-engaged approach is better suited to bringing about change - both within institutions of higher education and in society at large. Taking this advice to heart, our center has worked to ensure that our practicum course not only offers training in best practices for engaged pedagogy and public scholarship, but also creates space for graduate students to engage in critical conversations about the public mission of higher education and about the future roles they envision for themselves - on and off campus.

Our center's interest in creating professional development opportunities for graduate students that extend beyond training for tenure-track jobs has brought our work into productive dialogue with emerging efforts on our campus seeking to encourage diversity in career outcomes for graduate students. For instance, a new Graduate Professional Development Workgroup comprised of students, faculty, staff, and administrators recently called for a "culture shift" on our campus, and specifically urged faculty and senior administrators to acknowledge that "[p]reparing graduate students[ . . . ] who will contribute to a wide variety of occupations and fields, working with a diverse range of communities and publics, is one of the most important ways in which UCLA puts knowledge to work" (UCLA Graduate Professional Development Workgroup Report, 2015, pp. 2, 17). Our center has been collaborating with workgroup members and other campus leaders, such as deans and department chairs, to emphasize that the work of public engagement can and should take place not only in students' future careers but also during graduate study. Indeed, we argue that providing graduate students with opportunities to participate in community-engaged teaching and research during their degree programs is one of the best ways to ensure future graduates are prepared to engage in professional activities as public scholars, both within and beyond academia.

Recent scholarship supports this position and also reminds us that while the contributions graduate students make to society may include entering workforces outside the academy after graduation, the stakes in integrating community engagement into graduate education are much higher than simply opening up prospects for so-called "alternative" careers (Gilvin et al., 2012; Post et al., 2016). Indeed, the stakes for engaged graduate education extend and deepen what scholars of community engagement already know to be true of undergraduates: namely, that students who participate in academically rigorous and mutually beneficial collaborations with community partners not only develop foundational skills in areas that prepare them for a wide range of careers, such as project management and cross-cultural communication, but also - and more importantly - learn to recognize they have both the ability and the responsibility to put their college education to work for the greater good of society. That is to say, engaged students - whether undergraduate or graduate students - learn to see themselves as what Sullivan (1995) has termed "civic professionals."

Building on Sullivan's work, numerous scholars have examined the role of civic professionalism in undergraduate education and faculty development (Bender, 2001; Boyte \& Fretz, 2011; Peters, 2003; Koritz, Schadewald, \& Hubert, 2016), and Sullivan (2016) recently explored the benefits of incorporating civic professionalism into graduate education at the master's level, specifically in professional fields such as pharmacy and engineering. ${ }^{7}$ But core concepts from this theoretical framework - particularly the idea that an "apprenticeship of professionalism and purpose" should accompany disciplinary and practical training (Colby \& Sullivan, 2008, p. 410) - also resonate with recent efforts to shift away from the disciplinary guild model of graduate education and toward asset-based models of graduate professional development that affirm the "complex commitments" and diverse goals students bring 
with them to advanced study (Bartha \& Burgett, 2014, p. 39). In the following section, UCLA graduate students reflect on our campus's ongoing efforts to help graduate students develop as civic professionals. Throughout this discussion, we connect the story of our team's work with efforts underway at peer institutions to highlight broader shifts in the academic culture and engagement practices of research universities.

\section{Student Perspectives on Engaged Graduate Education}

\section{Our Approach to Values-Engaged Inquiry}

As detailed in the introduction, this essay employs the emerging theoretical framework of values-engaged assessment to examine the Center for Community Learning's new practicum course and larger trends in engaged graduate education at American research universities. As Bandy et al. (2016) explain, "Values-engaged assessment offers no one method, no one-size-fits-all approach to assessment [but] favors processes that are purposedriven, collaborative, empowering, dynamic, and context-dependent" (p. 99). The case studies produced by Imagining America's APPS working group to date showcase the wide range of methods that researchers have begun using to develop rich, values-engaged project narratives - often by blending qualitative approaches common to social science research (such as surveys, interviews, participant observation, and ethnography) together with more humanistic approaches to gathering, refining, and sharing stories of campus/community collaborations (such as story circles and scripted dialogues). ${ }^{8}$ The narrative developed by our team at UCLA synthesizes participant observations from the author and student contributors, and blends those observations together with first-person stories from the students, using a collaborative process described in more detail below.

In keeping with the ethos of full participation that undergirds values-engaged inquiry (Sturm et al., 2011), all nine graduate students who enrolled in our winter 2017 seminar at UCLA were invited to help set the parameters for a collaborative effort to document and assess the course. Early in the quarter, students were presented with a draft version of the literature review for this article and invited to contribute to the developing publication by offering general feedback on the draft, contributing anonymously to portions of the narrative describing the development and implementation of the course, and/or adding their first-person voices to the discussion of engaged graduate education; students also had the option to decline to participate. Five of the nine students agreed to contribute their personal stories to this section of the article with attribution, three elected to contribute general information to the framing narrative, and one (who graduated immediately after completing the course) opted not to contribute but did not object to the course being the subject of a publication.

The five graduate students who agreed to contribute stories to this project are at various stages in their degree programs, ranging from their second to ninth year of graduate study at UCLA. Each student's decision to enroll in a course focused on community-engaged teaching and research suggests that the students were already predisposed to value such work. As a further limitation, although the five students represent a notably diverse crosssection of UCLA's doctoral degree programs - with two students enrolled in the English department and the others enrolled in Education, History, and Public Health - they nonetheless account for a small percentage of UCLA's total graduate student population (which numbered 12,675 students in the fall of 2016). ${ }^{9}$ While the small number of self-selecting participants limits the scope of this research project in some ways, it is crucial to remember that valuesengaged assessment "evidence[s] less concern with generalizability than many social science [research frameworks]" and instead prioritizes collaborative and reciprocally generative methods of analyzing - and reporting on - engagement work (Bartha \& Nigro, 2013, n.p.). In the context of this project, our team's shared commitment to the APPS values of collaboration, reciprocity, and generativity dictated that the five graduate students who agreed to share their stories would be active, named contributors to this article rather than passive research subjects. This commitment to affirming student agency not only guided our collaborative writing process but also shaped how we conceptualized gathering evidence to support our claims.

Adopting an approach that was at once rigorous and practical for the tight time frame of UCLA's quarter system, I corresponded and met frequently with the five students who contributed to this article both during winter quarter and during the spring and summer of 2017. I shared observation notes I had taken during class discussions and worked together with the students to identify themes to focus on for publication that were based on topics we all agreed had figured prominently in seminar meetings and in the reflective writing assignments students had submitted to the online discussion forum for the course. Instead of treating student writing assignments as static data, the five student contributors used their reflection assignments as a 
springboard for developing stories that contributed to the essay's analysis of engaged graduate education in more collaborative and generative ways. In keeping with these values, the students lightly edited their coursework when doing so helped make their stories legible to a wider audience beyond our class, and some students also elected to write new material inspired by points they had raised in class discussions in order to help the team develop a more comprehensive narrative about our course and about engaged graduate education more broadly. The entire article received several rounds of rigorous review by all contributors to ensure that the narrative presented here is consistent with the observations and experiences of all participants. ${ }^{10}$

In the section below, student stories appear as block quotes attributed to an individual by name in order to make it easier for readers to identify and follow individual voices while simultaneously experiencing a collaborative conversation that advances through four interconnected themes. First, the students discuss the challenges they have experienced pursuing community engagement at a large public research university. After establishing this context, the students suggest strategies for ensuring that universities adequately recognize - and fund - the labor of engaged teaching and research. The group then reflects on the opportunities and challenges of institutionalizing and sustaining graduate engagement programs. Finally, the team highlights some of the benefits that stem from taking an assetbased approach to engaged graduate education in order to set the stage for the recommendations section that follows. My own voice appears throughout this section as well, but primarily serves to highlight common threads among the students' stories, and situates their reflections in the context of critical conversations and national trends regarding the public impact of graduate education. Rather than advancing claims distinct from those voiced by the students, my commentary serves to weave the five unique student voices into a larger conversation demonstrating what we have learned together about our institution and about the prospect of advancing engaged graduate education at large research universities such as UCLA.

\section{Four Interconnected Themes}

Barriers to engaged graduate education. The graduate students who joined our center's inaugural practicum course welcomed the opportunity to reflect on the current state of engaged graduate education at UCLA and organize for the future. Many students were quick to note that the disciplinary guild model of graduate education is, indeed, deep- ly entrenched at elite research universities such as UCLA - and has a negative impact on their ability to participate in engaged teaching and research:

Carrie Sanders: I think history as a discipline provides a fairly good platform for community engagement but in my experience as a graduate student, studying and teaching public history is not encouraged unless you are enrolled in a school with a public history program or your dissertation subject matter is particularly public-oriented. This discourages many graduate students from relating their work and interests to an audience beyond the elite professoriate.
Jonathan Banfill: I am currently a PhD student in education, in a division that is really a col- lection of educational sub-fields, all with more or less cross-disciplinary foundations. When I entered the program, I thought this would make for a rich intellectual space, with students shar- ing ideas across these differences and working together - yet this wasn't the case. The micro- divisions among students and faculty seemed to amplify anxieties about the "right" way to do research that in turn made for a lack of in- tellectual openness. As an undergraduate, I re- ally valued service-learning and study abroad experiences that were cross-disciplinary and collaborative but that sort of work seemed very much against the ingrained socialization within a single discipline that I found at UCLA.

These stories echo observations made by O'Meara (2008), O'Meara and Jaeger (2006), and Stanton and Wagner (2010) about how disciplinary silos organize - and often restrict - intellectual activity at research universities, and by extension hinder engaged teaching and research. In the second example, we also hear echoes of Stanton and Wagner's claim that students often find their graduate education lacking the sorts of opportunities for engagement available to them as undergraduates.

Graduate students earning degrees in departments with an established history of offering community-engaged courses in UCLA's undergraduate curriculum - such as English - also noted that few opportunities for engaged learning exist at the graduate level in their disciplines:

Vanessa Febo: As an instructor for the En-
glish 195CE undergraduate internship course
at UCLA's Center for Community Learning, I
have seen the benefits of fully integrating civic
professionalism into the classroom first-hand.
While my students gain professional experi-
ence as interns, they simultaneously explore
how humanistic inquiry can help them to an- 
alyze the impact that their potential future careers will have on local, national, and even international communities. In contrast, graduate students in the humanities are trained almost exclusively to be experts in a discipline - and all too often, this is at the expense of developing professional working skills and at the expense of understanding and critiquing their role within the structures of higher education and the larger structures of society.

Indeed, even a student in a more overtly applied fields - such as public health - reported that narrow definitions of what expertise could or should look like at the graduate level resulted in theoretical training taking precedence over practical engagement with community partners in their graduate coursework at UCLA:

Sarah Roth: As a doctoral student in public health without an MPH degree, I was required to enroll in the year-long course series that constitutes the foundation of knowledge for master's students in our department during my first year. Although our discipline is dedicated to understanding the dynamic relationships between community and health, these courses offered minimal opportunity to engage with the real world. I see this as a huge loss for both the department and the students in the program. In order to be effective practitioners, I believe, public health students need more experience building strong, reciprocal relationships with community partners.

Both of these stories highlight the lost opportunities - for students and departments, but also by extension for communities - that result when research universities fail to engage graduate students in the sorts of purposeful, course-base engagement often available to undergraduates. For instance, while students earning master's degrees in public health (MPH) at UCLA are required to complete an intensive summer internship, students earning doctorates in that field (such as the student above) are not required to complete such a program - and even the MPH students complete their internships as independent studies, without the sort of course-based discussion and reflection typical of undergraduate service-learning. In the absence of such opportunities, graduate students struggle to develop as civic professionals - and also struggle to develop the skills associated with their respective disciplines to their fullest potential.

During class discussions and assignments, our practicum participants frequently noted that they struggled to find time to engage with community partners because their schedules were already overloaded with personal and professional commitments, as reflected in the stories below:

Sarah Roth: As a graduate student, I feel an immense pressure to be involved in a thousand things - coursework, teaching, research, finding funding, community service, professional service, etc. Even in an applied, communityfocused discipline such as public health, we prioritize publishing in peer-reviewed journals over other types of output, and teaching is often viewed as a means to get tuition funding, not as a valuable use of time. I am lucky to have an advisor who not only values my interest in community-engaged research and teaching but also provides opportunities to get involved in the research he currently conducts with community partners.

Vanessa Febo: When my department secured a grant to offer stipends to graduate students who pursued summer internships, some people in the department expressed concerns that community work would distract us from our dissertation research. But graduate students have to work over the summer anyway, and while some of us fulfill that need through teaching, internships give us the chance to learn other professional skills. When some academics push community-engaged modes of learning to the side as extra-curricular activities or worse, as skills only needed by graduate students who wish to leave academia, universities are missing an opportunity to build a more informed and active body of scholars.

As these stories indicate, research universities all too often emphasize participation in traditional forms of scholarly activity at the expense of other investments that are priorities for students - such as the need to work to pay for tuition and other bills as well as genuine interest in community concerns. These pressures leave some students feeling that their graduate programs do not support their commitments and goals, while others are left feeling "lucky" if they do manage to find a mentor who supports their interest in community engagement.

Support strategies. During class discussions and assignments, our program participants emphasized that it becomes much more feasible for graduate students to participate in community engagement when they are able to link such activities to the sorts of research and teaching positions that help offset the costs of graduate study by providing tuition and fee remissions as well as a salary or stipend. We revisit this point in the recommendations that follow, but it is important to note that this call for more targeted funding aligns with best practices 
already in place at some of UCLA's peer institutions. The Rackham Program in Public Scholarship at the University of Michigan provides stipends to support engaged teaching and research, for example, and the University of Wisconsin-Madison supports the community-engaged research of graduate students through its Public Humanities Exchange. Within the University of California (UC) system, UC Irvine supports graduate students involved in public engagement through the Humanities Out There program, and UC Davis recently launched a new Mellon Public Scholars Program to support engaged research by graduate students. ${ }^{11}$ Similar to the teaching and research positions offered by the Center for Community Learning and by a handful of UCLA departments, these programs at peer institutions validate the labor of graduate student engagement by funding that work at a level commensurate with other sorts of funding available to graduate students.

As another form of validation, students in the practicum also strongly recommended embedding engagement in the graduate curriculum. One participant noted that this approach would build on established best practices for institutionalizing engagement in undergraduate education:

Alexandra Verini: When I taught an undergraduate service-learning class, I noticed that my students were able to bring their previous knowledge to the material they were encountering in and outside the classroom. This is a very different model from what I've typically found in my graduate education, where students are often reluctant to talk until they've mastered the prescribed discourse of their discipline. But many graduate students have work experience outside of academia and strong writing skills that make them very equipped to contribute to a community organization. For example, before graduate school, I was a teacher and coordinator in several non-profit ESL programs. I think that the feelings of isolation and imposter syndrome that many graduate students experience would be ameliorated by community-engaged work since it recognizes other sources of expertise.

As this story suggests, credit-bearing courses on engaged pedagogy and public scholarship - such as our practicum - not only help mitigate the sense that engagement work must compete with other components of graduate degree programs for students' limited time but also help transform the culture of research universities by creating spaces that value other sorts of knowledge in addition to disciplinary expertise.

In class discussions and assignments, our stu- dents indicated that they appreciated the opportunity to come together in our seminar to learn best practices to apply in their own teaching and research - but they also repeatedly stressed that they want UCLA to offer graduate students more than a lone practicum course focused largely on pedagogy. While our students valued the prospect of being prepared (and hopefully one day hired) to teach engaged courses in the future, they were adamant about wanting our campus to offer courses at the graduate level that would allow them to collaborate directly with community organizations through service-learning and engaged research, as described below:
Sarah Roth: I have found that community- engaged teaching and research opportunities such as our practicum course provide a unique opportunity for graduate students to engage across disciplines. These relationships are im- portant because interdisciplinary efforts are needed to tackle the tough challenges we face in the 21 st century. I would love to see UCLA offer courses in the future that would create opportunities for teams of graduate students to work with community partners on projects that would allow students to hone the professional skill sets for their disciplines and simultane- ously allow community groups to build their own organizational capacity. For example, En- glish and public health students could work to- gether by writing scripts and developing short videos for a health communication project.

The prospect of working in interdisciplinary teams with other graduate students and with community partners excited many of our students. Recognizing how rare such opportunities are at UCLA, many of the students in our course chose to fulfill the final assignment for the practicum - designing a syllabus for an engaged course - by drafting the type of curriculum they found to be lacking in their own graduate education. The student above, for instance, proposed an interdisciplinary course to tackle housing and homelessness, while other public health students designed graduate courses on nutrition and mental health. A student in education designed a graduate course on cultural memory and urban change.

Notably, sparking student interest in designing engaged graduate courses was not an explicit goal of our practicum at the outset. Our center mistakenly assumed that students who enrolled in our course would approach it much like teaching practica that already exist in other departments on our campus, the majority of which focus on preparing graduate students to teach undergraduates. To be sure, graduate students in UCLA's professional schools 
- including the Fielding School of Public Health and the Graduate School of Education and Information Studies - have few opportunities to serve as teaching assistants for undergraduate courses. UCLA's professional schools have much lower undergraduate enrollment than our College of Letters and Science, and so some might say that it is only logical that professional school students might be more interested in designing courses for their peers. But even students who used the final project for our practicum as an opportunity to design a community-engaged undergraduate course welcomed the opportunity to extend what we learned in class to imagine an engaged graduate curriculum as well, as reflected in the quote below:

\begin{abstract}
Alexandra Verini: I would really like to see UCLA create a graduate course on humanities public scholarship that engages in a reciprocal partnership with a community organization. I'm not entirely sure what this would look like, but I could, for instance, imagine graduate students working with an education organization - perhaps to tell the stories of a group of participants or to create a record of an organization's history or to develop a curriculum. These kinds of opportunities would allow humanities graduate students to think about how their reading and writing skills could later be put to broader use while also immediately benefitting a community organization.
\end{abstract}

This student's story registers a deep desire to push beyond the confines of traditional disciplinary training to put the skills graduate students are already cultivating to work in the world. While enrollment for our pilot course was relatively modest, this desire to reimagine the graduate curriculum at UCLA was prevalent among practicum participants, and suggests that our campus could benefit from further research to explore what sorts of communityengaged projects would be of interest to UCLA's diverse graduate student population.

Institutionalization: opportunities and challenges. At the Center for Community Learning, we are eager to support developing the sorts of communityengaged graduate courses that our students proposed, but gaining traction for engagement in the graduate curriculum - especially at an elite research university such as UCLA - will require significant buy-in from departments and divisions that grant advanced degrees. Thankfully, some units on our campus have been successful in securing seed funding to explore the role of community partnerships in graduate education - and some of the graduate students in our practicum course were participating simultaneously in those new initiatives. Doing so gave these students a unique perspective on the broader questions that motivated our practicum and that motivate this article's effort to assess the present state of engaged graduate education at UCLA and put forward recommendations for the future.

For instance, one practicum student who had struggled to find opportunities for engagement within his home department found much of what he was looking for in UCLA's Mellon-funded Urban Humanities Initiative:
Jonathan Banfill: I realized very early on that an individual department cannot hold all the re- sources that one needs to get the education and professional skills, as well as the intellectual satisfaction and growth, that I wanted from my time at UCLA - and so I joined UCLA's Urban Humanities Initiative, first as a student and lat- er in a paid position as a Graduate Student Re- searcher and Teaching Assistant. The program started out pretty theoretically oriented in the first year but over time, engaged research and scholarship entered more fully into the picture of UHI. Since 2016, I have helped plan short engaged projects/interventions with partners in Mexico City, Tokyo, and Los Angeles ad- dressing issues such as borders, commons, and sanctuaries.

In addition to interdisciplinary collaborations such as this one - which brought together faculty and students from Urban Planning, Architecture, and various humanities departments at UCLA to consult with academics and community leaders in several cities on the Pacific Rim - individual departments at UCLA are also piloting engagement opportunities for graduate students. ${ }^{12}$ These departmental initiatives have often emerged as part of national efforts to expand professionalization within letters and science disciplines and, in doing so, diversify career prospects for graduate students. The summer internship program mentioned above is one such program, funded by a Mellon Foundation grant to UCLA's English department. Our History department is also one of four campuses participating in the American Historical Association's Mellonfunded Career Diversity for Historians project, which made it possible for the department to launch a new graduate course that included opportunities for students to work on historical research projects for public audiences. ${ }^{13}$

One of our practicum participants - who spent several years leading one of our center's internship courses and encouraging undergraduates to reflect on their role as civic professionals - saw clear benefits in providing graduate students with similar course-based scaffolding for their forays into community engagement: 
Carrie Sanders: Part of the value of professionalization courses like the one recently offered in my department, "The Many Professions of History," is that they serve as a catalyst for conversations about the state of graduate student training but also offer practical opportunities for graduate students to work with community partners as civic professionals. Under my department's AHA/Mellon Career Diversity grant, I was hired to assist two teams of three graduate students tasked with creating a history-based executive brief for a private client. During this seminar, it became apparent that although graduate students have a lot to contribute to civic engagement, there were also areas in which students in their third and fourth years still struggled - giving a structured narrative to disparate sources, applying historical methodologies, and even writing clear, concise prose. Since presenting an excellent final product to the client was imperative, these issues were addressed throughout the course as they arose through continued feedback and draft revisions.

This student's story offers crucial insight about why integrating engagement into the curriculum of graduate degree programs is so vital: The structured environment of an academic course ensures that departments invest in supporting students as they refine the disciplinary skills that invigorate public scholarship, instead of relying on community partners to shoulder that burden or expecting students to develop such skills independently.

These developments on our campus align with recent efforts by the American Historical Association (Wood \& Townsend, 2013) as well as the Modern Language Association (2014) and National Institutes of Health (2012), to call attention to the myriad ways that participating in community engagement helps graduate students cultivate the sorts of flexible and creative problem solving skills that will allow them to keep pace with shifting trends in higher education and simultaneously prepare them for a wide range of careers - both within and beyond academia. Even graduate students who had not participated in formal career diversity programs on our campus often echoed these sentiments when making the case for increasing engagement opportunities for graduate students at UCLA:

Alexandra Verini: One of the most challenging things for me as I begin to think about possible careers outside of academia is the feeling that I have "wasted time." My graduate education has been entirely focused on preparing me for the kind of tenure-track job that, for many of us, is unattainable. As humanities research evolves, it is moving away from the scholar in an ivory tower model and increasingly involves interdisciplinary collaboration. I think incorporating community engagement into graduate curricula would help students prepare for these new models of research. But even more than that, it would make their education about more than preparation for a tenure-track job. It would focus graduate education not on a single outcome but rather on a set of versatile skills.

This student's story underscores how communityengaged learning can open up opportunities for graduate education to become more responsive to shifting trends within and across disciplines, which in turn makes graduate students more competitive for traditional tenure-track jobs while simultaneously helping them gain experience relevant to a wide range of other professions.

Cultivating this sort of versatility has been at the heart of various efforts to reimagine graduate education over the last several decades, but this goal has resurfaced with renewed force on our campus and others in recent years. ${ }^{14}$ Indeed, at UCLA, we have seen a call to change the story we have been telling about graduate professional development from a narrative mired in a rhetoric of crisis about the academic job market to one ripe with opportunity to engage graduate students in the public mission of higher education. As the authors of UCLA's Graduate Professional Development Workgroup Report (2015) explain, "[It is] important to see the present moment of crisis as an opportunity to forge new pathways of employment for our graduates and in ways that allow UCLA to realize its mission as a great public university" (p. 7).

Yet despite professed administrative support for initiatives that link graduate education with UCLA's public mission, some students who participated in our practicum noted that they have encountered resistance to the notion that graduate education could or should prepare students for careers beyond the professoriate:

Carrie Sanders: As Assistant Project Director for UCLA's career diversity pilot program in History, I expected the perceived binary between academia and the "real world" to be a frequent topic of concern during the program's development. What surprised me was that some of the loudest pushback came not from faculty, but from graduate students. Many said they found it "discouraging" and "depressing" that career diversity was being explored at an elite department - which, in turn, confused professors regarding how and whether to broach the topic at all. 
The feelings of frustration attributed here to both students and faculty, albeit in different ways, point to shared anxiety about how higher education should respond to the persistent encroachment of neoliberal values. Many graduate students are disillusioned to find that the tenure-track jobs they have spent years and tuition dollars training for are systematically being replaced with contingent positions - or eliminated entirely. But this trend is not new; it is simply now so widespread that even flagship research universities such as UCLA cannot guarantee that their graduate students will find full-time employment at a university, let alone on the tenure track at an institution of similar caliber. In the face of such trends, new commitment to tracking non-academic career placements can ring hollow, sounding to some skeptics like a "desperate" attempt by neoliberal administrations to "find measures justifying $\mathrm{PhD}$ production at a time when they can no longer pretend that the 'market' in tenure track jobs is going to turn around" (Bousquet, 2015, n.p.). Moreover, while some tenured and tenure-track faculty may be hesitant to admit that higher education's system of disciplinary guilds (from which they derive job security) is unsustainable, other academics who embrace the idea of career diversity for the next generation of graduate students still worry that encouraging graduates to pursue employment off-campus may further destabilize neoliberal labor markets by driving up the minimum credentials required to enter nonacademic careers (Posner, 2013).

Concerns about tension between democratic and neoliberal motivations for campus/community partnerships are very real and very troubling - and they have been addressed extensively by others (Brackman, 2015; Dixon \& Shotwell, 2012; Keene \& Reiff, 2017; Orphan \& O'Meara, 2016; Philion, 2017; Saltmarsh \& Hartley, 2016). For the purposes of this discussion, it bears noting that neoliberalism's encroachment on higher education simultaneously exposes inherent structural flaws in the assumptions that underpin the disciplinary guild model of graduate education - and this exposure can be generative. As one of our practicum participants explained,

Carrie Sanders: It seemed that much of the anxiety about this new elective course - "The Many Professions of History" - stemmed from the misconception that the skills one uses as a scholar are so extraordinary and rarified as to be completely separate from the skills required to function in other professional scenarios. But while the course objective was to place history outside the university, the skills refined by that work aren't "transferable skills" - they're foundational skills of historical inquiry that are vital to the professoriate as well as other professions.

As this story demonstrates, participating in academically rigorous and mutually beneficial collaborations with community partners can lead graduate students to recognize that they and their universities have not only the ability but also the responsibility to put disciplinary expertise to work beyond the confines of the proverbial ivory tower. By "leverag[ing] the academy for changing the world" in these ways (Dixon \& Shotwell, 2012, p. 336), community engagement experiences help graduate students envision themselves as civic professionals.

In addition to the empowerment that our students found in being able to reframe so-called "transferable" skills in public engagement as foundational to disciplinary practice, students in our practicum course also noted that they benefitted greatly from opportunities to take ownership over their engagement work:

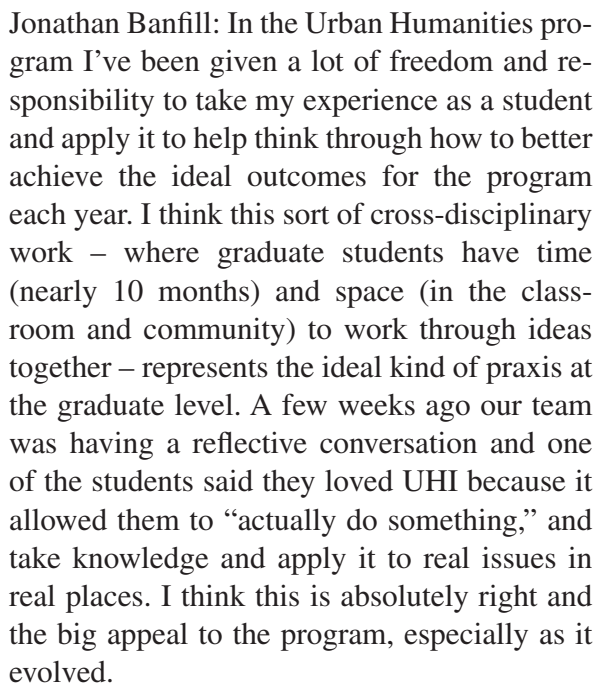

This story highlights how welcoming input from student leaders can help engagement programs respond to challenges that might otherwise pose barriers for potential participants - such as time constraints and perceived disciplinary boundaries. The blend of freedom and responsibility experienced by graduate students involved in UHI also exemplifies the sort of engaged graduate education that Orphan and O'Meara (2016) contend serves as a "powerful lever" for resisting the encroachment of neoliberalism in higher education and in society by "scaffold[ing] graduate student agency" (p. 224).

Benefits of asset-based approaches. Our center's practicum course - and this collaborative essay work to engage graduate students as agents of both social and institutional change by creating formal 
pathways for students to assess the present state of engaged graduate education and help to shape future directions. Through this emphasis on student agency, our efforts align not only with Orphan and O'Meara (2016) but also with calls to expand assetbased approaches to engaged graduate education advanced by Gale (2012) and Bartha and Burgett (2014). Approaching engaged graduate education in these ways can have transformative benefits for students, as evidenced by the stories above, and as another program participant explained:

\begin{abstract}
Sarah Roth: Prior to enrolling in the Center for Community Learning's practicum course, I did not really consider a career in academia. Rather, I saw my $\mathrm{PhD}$ training as a steppingstone towards a career in applied research in a community-based organization. However, during one of the class discussions, we talked about academic careers at higher education institutions with equity, engagement, and empowerment at the heart of their mission. This conversation helped me realize that teaching (with a community-engaged approach) is an important component of my own efforts to build a more equitable and just society. Accordingly, this realization has made me rethink academia as a potentially viable career path for me.
\end{abstract}

Here we see that, far from turning students away from academic careers, engaged graduate education increases the options available to students, making it easier for them to claim the sorts of agency that allow them to see themselves as able to choose career paths that speak to their values.

As Bartha and Burgett (2014) contend, engaged graduate students such as those enrolled in our practicum require and deserve professional development programs that validate their "complex commitments" and help them put their advanced education to work for the greater good of communities beyond campus - and in the service of institutional change on campus (p. 39). Offering our practicum as a formal course instead of an informal workshop series is one way that our center has begun creating infrastructure to support this sort of transformational engaged learning for graduate students. Ensuring that the course would be able to count as an elective for a new graduate certificate in writing pedagogy has added further institutional support. In a similar vein, the history department's "Many Professions of History" course counts as an elective for the doctoral program, and the team leading UCLA's Urban Humanities Initiative has taken steps to embed their program within graduate and undergraduate curricula:
Jonathan Banfill: I think we are still figuring exactly what the future of UCLA's Urban Humanities Initiative looks like, but some processes are underway to institutionalize the program after the next grant runs out (after 2019). We have already established a graduate certificate in urban humanities and we are working on developing an undergraduate minor. That will go a long way to making the program sustainable while also providing some more TA/GSR positions to support and involve graduate students.

At the Center for Community Learning, we have a long history of supporting engagement in the undergraduate curriculum - including courses in history and throughout the humanities and social sciences - and we are excited to be embarking on conversations with deans and faculty, as well as students, about how our center's work to advance engaged graduate education can integrate most effectively with efforts initiated in other areas of campus.

Embedding community engagement within degree programs has been crucial to sustaining support for such work within undergraduate education (Zlotkowski, 2005), and so it is not surprising to find that some research universities are even farther along than UCLA when it comes to establishing formal certification programs in community engagement or public scholarship for graduate students. Notable programs offering this expanded level of professional development include the University of Washington's Certificate in Public Scholarship and Michigan State University's Graduate Certification in Community Engagement. ${ }^{15}$ Some universities, including Brown and Yale, already offer master's degrees in public humanities and related fields and doctoral programs with an explicit emphasis on public scholarship are beginning to emerge as well, such as the $\mathrm{PhD}$ in Interdisciplinary Humanities and Public Humanities currently in development at Georgetown. Programs such as these helped inspire our center's efforts to work with campus partners to embed community engagement in the graduate curriculum at UCLA.

That said, our greatest inspiration continues to be the engaged graduate students mobilizing across our campus to advocate for social and institutional change. These students remind us time and again that research universities have a responsibility to help graduate students cultivate their diverse commitments and build skills that go above and beyond disciplinary expertise:

Vanessa Febo: Whether we plan to work in academia or beyond, graduate students would benefit greatly from courses that train them to better understand what it means to be a professional at a graduate level. I have seen how 
working with community leaders to develop projects rooted in scholarship benefits my undergraduate students and the communities where they work. Graduate students deserve these opportunities too. We need to recognize that our work has to speak to audiences beyond academia as we are already embedded in local and global communities and will continue to be tied to communities when we graduate. Acknowledging that we have a responsibility to the public informs and deepens scholarship - it is crucial to improving the structure of higher education.

Here, again, we see engaged graduate students calling for education that speaks to their commitments and values. At the UCLA Center for Community Learning we are responding to this call by centering our program planning and assessment efforts on examining how well an engagement initiative (such as our center's practicum course) lives up to the values we share with our students (such as a commitment to grounding all aspects of engagement work in an ethos of full participation for all stakeholders). In this way, we hope to ensure that UCLA graduate students have agency in determining what sorts of professional development opportunities will be available to them and in how those opportunities will be woven into campus infrastructure. The following section extends this reflective process beyond UCLA and aims to initiate further conversation about best practices for sustaining and growing engaged graduate education.

\section{Recommendations}

When those who are committed to the transformational power of engaged graduate education take a values-engaged approach to such work, it becomes possible to recognize that whether engaged graduate students go on to become engaged professors is, in many ways, beside the point. Transforming graduate education so that graduate students have opportunities to put their commitments and skills to work for institutional and social change during their course of study emerges as a worthwhile enterprise in and of itself. The programmatic structures best suited to support and sustain transformational models of engaged graduate education will likely vary depending on specific institutional and community contexts, as Bartha and Burgett (2014) rightly suggest. But with that caveat in mind, our team at UCLA offers the following recommendations for research universities interested in engaging graduate students more fully in the public mission of higher education. Each recommendation below includes a brief discussion of the pivotal role that campus-based centers for community engagement can play in such efforts, and highlights potential limitations and areas requiring further research. We invite colleagues on other campuses to join us in continuing these conversations.

1. Build traction for engaged graduate education at research universities by positioning such work as a complement to disciplinary training - and a form of disciplinary cross-training. As the stories of our practicum participants demonstrate, communityengaged teaching and research offer exciting opportunities for graduate students to collaborate with community leaders on projects that apply foundational skills from a wide range of academic disciplines to build capacity within communities. However, our experience at UCLA also suggests that graduate departments may be prone to framing forays into community engagement in terms of the sorts of consulting relationships that are familiar from professional fields, such as urban planning and medicine. While consultancy does constitute one way that academics contribute to society, positioning community members as "clients" in need of "interventions" (terms that surfaced in regards to some of the projects shared by our practicum participants) risks reinforcing technocratic hierarchies that have historically privileged academic expertise over community knowledge. Campus-based centers for academic civic engagement are ideally positioned to work with departments to critically examine power dynamics in proposed partnerships, with an eye toward developing graduate courses and research programs that are not only innovative and interdisciplinary, but also reciprocally beneficial for all stakeholders - on and off campus. Such partnerships are ideally suited to address the complex challenges facing communities in the twentyfirst century, and have the added benefit of providing graduate students with experience collaborating with diverse groups, thus building skills in crosssectoral and cross-cultural communication that prepare students for twenty-first-century careers both within and beyond the academy.

2. Leverage existing infrastructure to fund and support engaged graduate students whenever possible - and explore new programmatic structures and creative funding arrangements as needed. By integrating engagement opportunities into graduate coursework and into the sorts of teaching assistantships and research positions already available to students, research universities can help keep program costs low while simultaneously ensuring that graduate students who would like to pursue engaged work have the time and resources available to make their participation feasible. However, our team also recognizes that allocating existing 
resources to support engagement initiatives can pose challenges, particularly for public universities facing significant cuts in state and federal funding. Creative approaches will likely be required to make the most of limited internal resources and to succeed in increasingly heated competitions for external grants. In light of these challenges, our team encourages research universities to break out of disciplinary silos and pool funds to launch interdepartmental engagement opportunities. UCLA's Urban Humanities Initiative offers one such model, but other research universities have also achieved success with programs that serve students in multiple departments, as we noted in the previous section. Campus-based engagement centers have a long history of supporting collaborative curricular initiatives and can help develop models at the graduate level that respond creatively to resource constraints, while simultaneously grounding engagement programs in the sorts of interdisciplinary approaches that our practicum participants found both intellectually stimulating and ideally suited to addressing the complex challenges of the twentyfirst century.

3. Position graduate student development as civic professionals as central to the public mission of higher education, and particularly crucial to the mission of research universities. Even more so than undergraduates, graduate students are ready to take leadership roles in community engagement initiatives and in their own education; they require and deserve engagement programs that build on the strengths that brought them to graduate study and help them put those assets to work for the good of society - as civic professionals. Since research universities serve the majority of graduate students in the United States (and an even larger percentage of doctoral students), they have a key role to play in advancing civic professionalism in graduate education - but we also recognize that other types of institutions serve graduate students, and we invite colleagues from other campuses to complicate the narrative we offer here. ${ }^{16}$ Further research will also be needed to explore how training in civic professionalism can best support the academic and career goals of graduate students earning master's degrees and professional doctorates as well as those earning PhDs. Campus-based community engagement centers have a crucial role to play in ongoing conversations about career diversity for graduate students because such centers are ideally positioned to push back against narrow, neoliberal understandings of the value that graduate education brings to society. By working together with engaged graduate students, we can instead champion asset-based approaches to graduate student professional develop- ment that are better suited to initiating and sustaining transformative institutional and social change.

4. Pursue ongoing values-engaged assessment with all stakeholders involved in engaged graduate education. For far too long, graduate student voices have been largely absent from critical conversation about best practices for campus/community partnerships, and the same can be said for the perspectives of community partners. ${ }^{17}$ More research is needed if we are to understand the complexity of these relationships, but thankfully the emerging field of values-engaged assessment offers exciting possibilities for grounding efforts to document and analyze campus/community partnerships in the ethos of full participation (Bandy et al., 2016; Sturm et al., 2011). Centers that specialize in bridging university and community stakeholders are particularly equipped to support asset-based, values-engaged models of program planning and assessment. Our team at the UCLA Center for Community Learning thus joins members of the SLCE Future Directions Project and Imagining America's Assessing the Practices of Public Scholarship working group in urging colleagues to share stories of their experiments with values-engaged assessment so that we can collaborate to chart the ongoing evolution in best practices for engaged graduate education - and for campus/community partnerships. ${ }^{18}$

\section{Conclusion}

Those of us working in academic community engagement at research universities have a unique opportunity - and a responsibility - to work together with engaged graduate students to shape how our universities put the emerging discourse of asset-based graduate professional development into action. If we sit idly by, far too many resourcestrapped research universities, particularly large public universities like UCLA, are likely to fall back on business as usual - quite literally, they will fall back on defining the engagement that graduate students have with communities beyond campus largely in terms of the sorts of translational research that can be patented and sold or distributed through pro-bono consulting networks. While such initiatives definitely contribute to society, we will do our graduate students a grave disservice if we assume they have no other assets to offer the public. For indeed, as Stanton and Wagner (2010) note, the historic "segregation between civic engagement and graduate education diminishes the vitality of graduate education itself and marks a problematic and glaring gap in the research university's social contract" (p. 419).

Thankfully, however, the assets graduate stu- 
dents bring to the public work of higher education are equally palpable - and if we join forces with them to create programs that tap into their diverse commitments and goals, together we can show our universities and our communities that graduate students have much more than patentable products and consulting services to contribute to the public. Indeed, when we place the strengths of our graduate students at the center of reciprocal relationships with community partners, research universities stand poised to transform the culture of higher education - making the institution itself more democratic, and at the same time becoming more effective partners for our students and our communities.

\section{Notes}

The author would like to thank all of the graduate students who have worked with the Center for Community Learning to advance UCLA's public mission - and particularly those who attended our summit on engaged graduate education in the fall of 2015, and those who participated in our inaugural practicum course in the winter of 2017. Special thanks are due to Jonathan Banfill, Vanessa Febo, Sarah Roth, Carrie Sanders, and Alexandra Verini, who actively collaborated in shaping this essay and contributed their personal stories. Numerous other colleagues at UCLA also helped bring this article to fruition, including Doug Barrera, Amber Brink, Christine Gottlieb, Molly Jacobs, Kathy O'Byrne, Val Shepard, and Lauren Willner. Gratitude is also due to Miriam Bartha, Kelly Anne Brown, Sylvia Gale, and other friends and colleagues who continue to inspire innovation in engaged graduate education - and to the editors and reviewers who offered valuable feedback on earlier versions of this article.

${ }^{1}$ The body of scholarship on community engagement in undergraduate education is too extensive to summarize here, but for an overview of recent trends in the field, see: Dolgon, Mitchell, and Eatman (2017); Fitzgerald, Burack, and Seifer (2010); Kezar, Chambers, and Burkhardt (2005); Saltmarsh and Hartley (2011); and Soria and Mitchell (2016).

${ }^{2}$ Bandy et al. (2016) note that the two halves of this central framework for values-engaged assessment are rooted in Saltmarsh, Hartley, and Clayton (2009) and Brackman (2015), respectively.

${ }^{3}$ Numerous scholars have examined the tenuous position of graduate students within the neoliberal university, but for an overview, see: Bousquet (2002, 2015), Dixon and Shotwell (2012); Gilvin (2012), and Orphan and O'Meara (2016).

${ }^{4}$ In making the decision to designate these graduate student collaborators as contributors rather than co-authors, our research team followed pro- tocols recently released by the International Committee of Medical Journal Editors (2013). The author conducted the background research for this article during the process of preparing the course proposal submitted to UCLA's Graduate Council in the spring of 2016, and she submitted a preliminary manuscript to MJCSL focused on the program planning process that summer. Although the five graduate students who contributed stories to this article in the winter and spring of 2017 also offered feedback on the larger argument of the essay, the students agree that these contributions do not meet the criteria required for co-authorship. While full co-authorship would be even more in line with the ethos of full participation that underpins valuesengaged assessment inquiry, the inclusion of stories attributed to multiple stakeholders by name still marks a significant departure from the data-driven case studies that have historically dominated higher education research - even in the field of campus/ community partnerships.

${ }^{5}$ A detailed discussion of engagement in professional graduate education falls outside the scope of this article, but it is important to note that four students from UCLA's Fielding School of Public Health enrolled in our center's practicum course two doctoral students and two students earning MPH degrees. Stories contributed by a student earning a $\mathrm{PhD}$ in Public Health suggest that students pursuing doctoral degrees in that field at research universities can face many of the same challenges vis-à-vis community engagement faced by doctoral students in other fields. Neither master's student was able to contribute to this article, but the research team made the decision to use the term "graduate students" rather than "doctoral students" throughout the article in order to acknowledge that master's students contributed to the classroom conversations that shaped this project - and in order to signal that further research is needed to explore how the experiences of engaged master's students compare to those of doctoral students, both within applied fields (such as public health) and more broadly.

${ }^{6}$ Examples of such summits include the Institute on the Public Humanities for Doctoral Students at the University of Washington that led to the creation of UW's Certificate in Public Scholarship (as documented in Bartha \& Burgett, 2014), the Institute on Engagement and the Academy hosted by the University of Iowa's Obermann Center for Advanced Studies, and the Institute for Social Change hosted by the Rackham Program in Public Scholarship at the University of Michigan. Imagining America's Publicly Active Graduate Education program also convenes a summit on engaged graduate education as part of IA's annual conference. 
${ }^{7}$ Sullivan's 2016 work extends his previous studies of academic and civic training in professional fields such as law and medicine. See, for example, Colby and Sullivan (2008) and Sullivan (2004).

${ }^{8}$ The case studies available on the APPS page of Imagining America's website generally offer brief overviews of approaches to values-engaged assessment. However, one case study links to a longer report produced by Alvarez (2009) that provides a more detailed example of one way APPS researchers have combined humanistic storytelling strategies (such as dialogues presented in script format) with journal entries and ethnographic observations to create rich narratives that give voice to multiple stakeholders involved in a campus/community partnership.

${ }^{9}$ UCLA enrollment figures are tracked by the university's Office of Academic Planning and Budget.

${ }^{10}$ Our decision to adopt a collaborative writing process was informed not only by values-engaged inquiry but also by research on the importance of engaging students as collaborators in engaged research and assessment (Battistoni \& Longo, 2011; Fretz \& Longo, 2010; Longo, Kiesa, \& Battistoni, 2016). Collaborative autoethnography offers one methodological precedent for this sort of effort to analyze and write about shared experiences collaboratively, with the goal of gaining insight not only about the self but also about society (Chang, Ngunjiri, \& Hernandez, 2013). This APPS case study of Roadside Theater's use of "evaluation story circles" offers another example of how individual stories evolve when shared in the context of collaborative reflection, resulting in a thick, polyvocal story that offers both contributors and outsiders new insights on a group experience.

${ }^{11}$ See Day, Becerra, Ruiz, and Poe (2012) for a detailed analysis of Humanities Out There that underscores the importance of funding the labor of engaged graduate students.

${ }^{12}$ For more information about the Urban Humanities Initiative at UCLA, see MacDonald (2016).

${ }_{13}$ See Freeling (2017) for more information about the Career Diversity for Historians project and other UC-wide efforts to provide graduate students with opportunities to put their skills to work in community contexts, such as the Humanists@ Work initiative based out of the UC Humanities Research Institute at UC Irvine.

${ }^{14}$ See Weisbuch and Cassuto (2016) for an overview of efforts to reimagine doctoral education since 1990.

${ }^{15}$ For more information on these programs, see Bartha and Burgett (2014) and Matthews et al. (2015).
${ }^{16}$ See Allum (2014) for data on graduate student enrollment trends across different institutional contexts.

${ }^{17}$ On the absence of community partner perspectives in the scholarship on campus/community partnerships, see Stoecker, Tryon, and Hilgendorf (2009).

${ }^{18}$ The SLCE Future Directions Project offers a standing call to contribute via the project website.

\section{References}

Allum, J. (2014). Graduate enrollment and degrees: 2003 to 2013. Washington, DC: Council of Graduate Schools. Retrieved from http://cgsnet.org/ckfinder/userfiles/files/GED_report_2013.pdf

Alvarez, M. (2009). Two-way mirror: Ethnography as a way to assess civic impact of arts-based engagement in Tucson, Arizona. Retrieved from http://animatingdemocracy.org/sites/default/files/Two-Way\%20Mirror.pdf

American Historical Association. (n.d.). Career diversity for historians. Retrieved from https://www.historians. org/jobs-and-professional-development/career-diversity-for-historians

Applegate, J. L. (2002). Engaged graduate education: Seeing with new eyes. Washington, DC: Association of American Colleges \& Universities. Retrieved from http://archive.aacu.org/pff/pdfs/PFF_Applegate.PDF

Austin, A. \& Barnes, B. J. (2005). Preparing doctoral students for faculty careers that contribute to the public good. In A. J. Kezar, T. C. Chambers, \& J. C. Burkhardt (Eds.), Higher education for the public good: Emerging voices from a national movement (pp. 272292). San Francisco: Jossey-Bass.

Austin, A. E. \& McDaniels M. (2006). Using doctoral education to prepare faculty to work within Boyer's four domains of scholarship. In J. M. Braxton (Ed.), Analyzing faculty work and rewards: Using Boyer's four domains of scholarship. New Directions for institutional Research (Vol. 129, pp. 51-65). San Francisco: Jossey-Bass.

Bandy, J., Bartel, A. S., Clayton, P. H., Gale, S., Mack, H., Metzker, J., et al. (2016). Values-engaged assessment: Reimagining assessment through the lens of democratic engagement. Michigan Journal of Community Service Learning, 23(1), 96-101.

Bartha, M. \& Burgett, B. (2014). Why public scholarship matters for graduate education. Pedagogy: Critical Approaches to Teaching, Literature, Language, Composition, and Culture, 15(1), 31-43.

Bartha, M. \& Nigro, G. (2013). Assessing the practices of public scholarship. Diversity and Democracy, 16(3). Retrieved from http://www.aacu.org/diversitydemocracy/2013/summer/bartha-nigro

Battistoni, R. M. \& Longo, N. V. (2011). Putting students at the center of civic engagement. In J. Saltmarsh \& M. Hartley (Eds.), "To serve a larger purpose": Engagement for democracy and the transformation of 
higher education (pp. 199-216). Philadelphia: Temple University Press.

Bender, T. (2001). Then and now: The disciplines and civic engagement. Liberal Education, 87(1), 6-17.

Bousquet, M. (2002). The waste product of graduate education: Toward a dictatorship of the flexible. Social Text, 20(1), 81-104.

Bousquet, M. (2015, October 20). Moving the goalposts in graduate education. Inside Higher Ed. Retrieved from https://www.insidehighered.com/ views/2015/10/20/phd-should-result-tenure-track-jobnot-alt-ac-one-essay

Boyer, E. L. (1990). Scholarship reconsidered: Priorities of the professoriate. Princeton, NJ: Carnegie Foundation for the Advancement of Teaching.

Boyer, E. L. (1996). The scholarship of engagement. Journal of Public Service and Outreach, 1(1), 11-20.

Boyte, H. C. \& Fretz, E. Civic professionalism. (2011). In J. Saltmarsh \& M. Hartley (Eds.), "To serve a larger purpose": Engagement for democracy and the transformation of higher education (pp. 82-101). Philadelphia: Temple University Press.

Brackman, S. M. (2015). Community engagement in a neoliberal paradigm. Journal of Higher Education Outreach and Engagement, 19(4), 115-146.

Brown University. (n.d.). Master's in public humanities. Retrieved from https://www.brown.edu/academics/ public-humanities/masters-public-humanities

Chang, H., Ngunjiri, F. W., \& Hernandez, K. C. (2013). Collaborative autoethnography. New York: Routledge.

Colby, A. \& Sullivan, W. M. (2008). Formation of professionalism and purpose: Perspectives from the preparation for the professions program. University of St. Thomas Law Journal, 5(2), 404-427.

Day, K., Becerra, V., Ruiz, V. L., \& Powe, M. (2012). New ways of learning, knowing, and working: Diversifying graduate student career options through community engagement. In A. Gilvin, G. M. Roberts, \& C. Martin (Eds.), Collaborative futures: Critical reflections on publicly active graduate education (pp. 163-182). Syracuse, NY: The Graduate School Press of Syracuse University.

Dixon, C. \& Shotwell, A. (2012). Leveraging the academy: Suggestions for radical grad students and radicals considering graduate school. In A. Gilvin, G. M. Roberts, \& C. Martin (Eds.), Collaborative futures: Critical reflections on publicly active graduate education (pp. 333-345). Syracuse, NY: The Graduate School Press of Syracuse University.

Doberneck, D. M., Brown, R. E. \& Allen, A. D. (2010). Professional development for emerging engaged scholars. In H. E. Fitzgerald, C. Burack, \& S. D. Seifer (Eds.), Handbook of engaged scholarship: Contemporary landscapes, future directions. (Vol. 1, pp. 391409). East Lansing, MI: Michigan State University Press.

Dolgon C., Mitchell, T. D., \& Eatman, T. K. (Eds.). (2017). The Cambridge handbook of service learning and community engagement. Cambridge, UK: Cambridge University Press. https://doi.org/10.1017/9781316650011
Dolson, T., Figura, B., \& Gale, S. (2016). Engaging assessment: Applying civic values to evaluation. $\mathrm{Di}$ versity and Democracy, 19(4). Retrieved from https:// www.aacu.org/diversitydemocracy/2016/fall/dolson

Driscoll, A. \& Lynton, E. A. (1999). Making outreach visible: A guide to documenting professional service and outreach. Washington, DC: American Association for Higher Education.

Eatman, T. K. (2012). The arc of the academic career bends toward publicly engaged scholarship. In A. Gilvin, G. M. Roberts, \& C. Martin (Eds.), Collaborative futures: Critical reflections on publicly active graduate education (pp. 25-48). Syracuse, NY: The Graduate School Press of Syracuse University.

Ellison, J. \& Eatman, T. K. (2008). Scholarship in public: Knowledge creation and tenure policy in the engaged university. Syracuse, NY: Imagining America. Retrieved from http://imaginingamerica.org/wp-content/ uploads/2015/09/TTI_FINAL.pdf

Fitzgerald, H. E., Burack, C, \& Seifer, S. D. (Eds.) (2010). Handbook of engaged scholarship: Contemporary landscapes, future directions. (Vols. 1-2). East Lansing, MI: Michigan State University Press.

Freeling, N. (2017, April 19). Grad students in humanities explore off-campus careers. Retrieved from http:// newsroom.ucla.edu/stories/grad-students-in-humanities-explore-off-campus-careers

Fretz, E. J. \& Longo, N.V. (2010). Students co-creating an engaged academy. In H. E. Fitzgerald, C. Burack, \& S. D. Seifer (Eds.), Handbook of engaged scholarship: Contemporary landscapes, future directions. (Vol. 1, pp. 313-329). East Lansing, MI: Michigan State University Press.

Gale, S. (2012). Arcs, checklists, and charts: The trajectory of a public scholar? In A. Gilvin, G. M. Roberts, \& C. Martin (Eds.), Collaborative futures: Critical reflections on publicly active graduate education (pp. 315-327). Syracuse, NY: The Graduate School Press of Syracuse University.

Georgetown University. (n.d.). PhD program in interdisciplinary and public humanities. Retrieved from https:// reinventphd.georgetown.edu/phd-working-group

Gilvin, A. (2012). Introduction. In A. Gilvin, G. M. Roberts, \& C. Martin (Eds.), Collaborative futures: Critical reflections on publicly active graduate education (pp. 1-21). Syracuse, NY: The Graduate School Press of Syracuse University.

Gilvin, A., Roberts, G. M., \& Martin, C. (Eds.). (2012). Collaborative futures: Critical reflections on publicly active graduate education. Syracuse, NY: The Graduate School Press of Syracuse University.

Golde, C. M. (2006). Preparing stewards of the discipline. In C. M. Golde \& G. E. Walker (Eds.), Envisioning the future of doctoral education: Preparing stewards of the discipline - Carnegie essays on the doctorate (pp. 3-20). San Francisco: Jossey-Bass.

Golde, C. M. \& Dore, T. M. (2001). At cross purposes: What the experiences of today's doctoral students reveal about doctoral education. Philadelphia: Pew Charitable Trusts. Retrieved from http://www.phd-survey.org/report.htm 
Imagining America. (n.d.). Case studies. Retrieved from http://imaginingamerica.org/case-studies/

Imagining America. (n.d.). Integrated assessment. Retrieved from http://imaginingamerica.org/initiatives/ integrated-assessment/

Imagining America. (n.d.). Looking out and looking in: Ethnographic evaluation as a two-way mirror. Retrieved from http://imaginingamerica.org/wp-content/ uploads/2015/09/Ethnographic-Evaluation.pdf

Imagining America. (n.d.). Story circles as ongoing and collaborative evaluation-Roadside theater's "story to performance." Retrieved from http://imaginingamerica.org/wp-content/up loads/2015/09/Story-Circles-as-Ongoing-and-Col laborative-Evaluation \%E2\%80\%94Roadside-The ater\%E2\%80\%99s-_Story-to-Performance_.pdf

Imagining America. (n.d.). Student engagement. Retrieved from http://imaginingamerica.org/student-engagement/

International Committee of Medical Journal Editors. (2013). Authorship \& contributorship. Retrieved from http://www.bmj.com/about-bmj/resources-authors/ar ticle-submission/authorship-contributorship

Keene, A. S. \& Reiff, J. (2017). To be or not to be political: Engagement and power. In C. Dolgon, T. D. Mitchell, \& T. K. Eatman (Eds.), The Cambridge handbook of service learning and community engagement (pp. 485499). Cambridge, UK: Cambridge University Press. https://doi.org/10.1017/9781316650011.035

Kezar, A. J., Chambers, T. C., \& Burkhardt, J. C. (Eds.). (2005). Higher education for the public good: Emerging voices from a national movement. San Francisco: Jossey-Bass.

Koritz, A., Schadewald, P., \& Hubert, H. (2016). Civic professionalism: A pathway to practical wisdom in the liberal arts (white paper). Imagining America: Artists and Scholars in Public Life. Retrieved from http:// imaginingamerica.org/wp-content/uploads/2016/12/ CivicProfessionalismWP.pdf

Longo, N. V., Kiesa, A., and Battistoni, R. (2016). The future of the academy with students as colleagues. In M. A. Post, E. Ward, N. V. Longo, \& J. Saltmarsh (Eds.), Publicly engaged scholars: Next-generation engagement and the future of higher education (pp. 197-213). Sterling, VA: Stylus.

MacDonald, M. (2016, June 29). UCLA receives \$1.65 million from Mellon Foundation to continue urban humanities program. Retrieved from http://newsroom. ucla.edu/dept/faculty/ucla-receives-1-65-millionfrom-mellon-foundation-to-continue-urban-human ities-program

Matthews, P. H., Karls, A. C., Doberneck, D. M., \& Springer, N. C. (2015). Portfolio and certification programs in community engagement as professional development for graduate students: Lessons learned from two land-grant universities. Journal of Higher Education Outreach and Engagement, 19(1), 157-183.

Michigan State University. (n.d.). Graduate certification in community engagement. Retrieved from http:// gradcert.engage.msu.edu/
Modern Language Association of America. (2014). Report of the MLA task force on doctoral study in modern language and literature. New York: Modern Language Association of America. Retrieved from https://www. mla.org/content/download/25437/1164354/taskforce docstudy2014.pdf

National Institutes of Health. (2012). Biomedical research workforce working group report. Bethesda, MD: National Institutes of Health. Retrieved from http://acd. od.nih.gov/biomedical_research_wgreport.pdf

O’Meara, K. (2008). Graduate education and community engagement. In C. L. Colbeck, K. O'Meara, \& A. E. Austin (Eds.), Educating integrated professionals: Theory and practice on preparation for the professoriate. New directions for teaching and learning (Vol. 113, pp. 27-42).

O'Meara, K. (2010). Rewarding multiple forms of scholarship: Promotion and tenure. In H. E. Fitzgerald, C. Burack, \& S. D. Seifer (Eds.), Handbook of engaged scholarship: Contemporary landscapes, future directions. (Vol. 1, pp. 271-293). East Lansing, MI: Michigan State University Press.

O'Meara, K. (2016). Legitimacy, agency, and inequality. In A. Post, E. Ward, N. V. Longo, \& J. Saltmarsh (Eds.), Publicly engaged scholars: Next-generation engagement and the future of higher education (pp. 96-109). Sterling, VA: Stylus.

O’Meara, K. \& Jaeger, A. J. (2006). Preparing future faculty for community engagement: Barriers, facilitators, models, and recommendations. Journal of Higher Education Outreach and Engagement, 11(4), 3-26.

O’Meara, K. \& Rice, R. E. (Eds.). (2005). Faculty priorities reconsidered: Rewarding multiple forms of scholarship. San Francisco: Jossey-Bass.

Orphan, C. M. \& O’Meara, K. (2016). Next-generation engagement scholars in the neoliberal university. In M. A. Post, E. Ward, N. V. Longo, \& J. Saltmarsh (Eds.), Publicly engaged scholars: Next-generation engagement and the future of higher education (pp. 214-231). Sterling, VA: Stylus.

Peters, S. J. (2003). Reconstructing civic professionalism in academic life: A response to Mark Wood's paper, "From service to solidarity." Journal of Higher Education Outreach and Engagement, 8(2), 183-198.

Philion, S. (2017). Engaging neoliberal community engagement: Research and organizing with immigrant workers. In C. Dolgon, T. D. Mitchell, \& T. K. Eatman (Eds.), The Cambridge handbook of service learning and community engagement (pp. 470-484). Cambridge, UK: Cambridge University Press. https://doi. org/10.1017/9781316650011.045

Posner, M. (2013, December 4). The jobs we want? Inside Higher Ed. Retrieved from https://www.insidehigh ered.com/advice/2013/12/04/essay-asks-whether-altac-careers-are-really-solution-academic-jobs-shortage

Post, M. A., Ward, E., Longo, N. V., \& Saltmarsh, J. (Eds.). (2016). Publicly engaged scholars: Nextgeneration engagement and the future of higher education. Sterling, VA: Stylus.

Roadside Theater. (n.d.). Story circles. Retrieved from https://roadside.org/program/story-circles 
Saltmarsh, J. \& Hartley, M. (Eds.) (2011). "To serve a larger purpose": Engagement for democracy and the transformation of higher education. Philadelphia: Temple University Press.

Saltmarsh, J. \& Hartley, M. (2016). The inheritance of next-generation engagement scholars. In M. A. Post, E. Ward, N. V. Longo, \& J. Saltmarsh (Eds.), Publicly engaged scholars: Next-generation engagement and the future of higher education (pp. 15-33). Sterling, VA: Stylus.

Saltmarsh, J., Hartley, M., \& Clayton, P. (2009). Democratic engagement white paper. New England Resource Center for Higher Education. Retrieved from http://repository.upenn.edu/gse_pubs/274

SLCE Future Directions Project. (n.d.). Retrieved from https://slce-fdp.org/

Soria, K. M. \& Mitchell, T. D. (Eds.). (2016). Civic engagement and community service at research universities: Engaging undergraduates for social justice, social change and responsible citizenship. London: Palgrave Macmillan.

Stanton, T. K. \& Wagner, J. (2010). Educating for democratic citizenship: Antecedents, prospects, and models for renewing the civic mission of graduate education at research universities. In H. E. Fitzgerald, C. Burack, \& S. D. Seifer (Eds.), Handbook of engaged scholarship: Contemporary landscapes, future directions. (Vol. 1, pp. 411-436). East Lansing, MI: Michigan State University Press.

Stoecker, R., Tryon, E., \& Hilgendorf, A. (2009). The unheard voices: Community organizations and service learning. Philadelphia: Temple University Press.

Sturm, S., Eatman, T., Saltmarsh, J. \& Bush, A. (2011). Full participation: Building the architecture for diversity and public engagement in higher education (white paper). Columbia University Law School: Center for Institutional and Social Change. Retrieved from http:// change-center.squarespace.com/publications/

Sullivan, W. M. (1995). Work and integrity: The crisis and promise of professionalism in America. New York: Harper Collins.

Sullivan, W. M. (2004). Can professionalism still be a viable ethic? The Good Society, 13(1), 15-20.

Sullivan, W. M. (2016). The power of integrated learning: Higher education for success in life, work, and society. Sterling, VA: Stylus.

UC Davis. (n.d.). Mellon public scholars program. Retrieved from http://publicscholars.ucdavis.edu/

UC Humanities Research Institute. (n.d.). Humanists@ Work. Retrieved from https://humwork.uchri.org/

UC Irvine. (n.d.). Public engagement: Humanities out there. Retrieved from http://sites.uci.edu/humanitie soutthere/
UCLA. (n.d.). Center for community learning. Retrieved from http://www.uei.ucla.edu/communitylearning.htm

UCLA. (n.d.). Enrollment. Retrieved from http://www. apb.ucla.edu/campus-statistics/enrollment

UCLA graduate professional development workgroup report. (2015). Retrieved from http://career.ucla.edu/ PhD-Masters-Career-Services

UCLA. (n.d.). Technology fellows program. Retrieved from http://tdg.ucla.edu/about-us/jobs-internships/ ucla-internships-technology-transfer-and-intellectu al-property-management

UCLA. (n.d.). Urban humanities. Retrieved from http:// www.urbanhumanities.ucla.edu/

University of Iowa. (n.d.). Graduate institute on engagement and the academy. Retrieved from https://obermann.uiowa.edu/programs/graduateinstitute

University of Michigan. (n.d.). Rackham program in public scholarship. Retrieved from https://www.rack ham.umich.edu/publicscholarship/

University of Michigan. (n.d.). Institute for social change. Retrieved from https://www.rackham.umich. edu/publicscholarship/institute/

University of Washington. (n.d.). Certificate in public scholarship. Retrieved from https://simpsoncenter.org/ programs/curriculum/certificate-in-public-scholarship

University of Wisconsin-Madison. (n.d.). Graduate exchange program. Retrieved from http://humanities. wisc.edu/public-humanities

Weisbuch, R. \& Cassuto, L. (2016). Reforming doctoral education, 1990 to 2015: Recent initiatives and future prospects. Retrieved from https://mellon.org/ resources/news/articles/reforming-doctoral-education-1990-2015-recent-initiatives-and-future-prospects/

Wood, L. M. \& Townsend, R. B. (2013). The many careers of history PhDs: A study of job outcomes, spring 2013 - A report to the American Historical Association. Washington, DC: American Historical Association. Retrieved from https://www.historians. org/jobs-and-professional-development/career-diversi ty-for-historians/career-diversity-resources/the-manycareers-of-history-phds

Yale University. (n.d.). Public humanities master's program. Retrieved from http://ph.yale.edu/masters-program-0

Zlotkowski, E. (2005). The disciplines and the public good. In A. J. Kezar, T. C. Chambers, \& J. C. Burkhardt (Eds.), Higher education for the public good: Emerging voices from a national movement (pp. 146165). San Francisco: Jossey-Bass. 
Author

ELIZABETH K. GOODHUE (bgoodhue@college.ucla.edu) is associate director for engaged teaching at the UCLA Center for Community Learning. In addition to overseeing the center's professional development initiatives for graduate students, she supports engaged curriculum development across campus, facilitates communityengaged pedagogy workshops, directs academic internships, and cultivates community partnerships. She regularly teaches service-learning courses on children's literature and childhood literacy and on public humanities theory and practice. She has authored several articles, including publications on service-learning in literary studies and, with colleagues from Imagining America, on the role of academic administrators as intermediaries bridging university and community stakeholders.

\section{Contributors}

The following UCLA graduate students contributed personal stories to the section of this article subtitled "Student Perspectives on Engaged Graduate Education": Jonathan Banfill (Education), Vanessa Febo (English), Sarah Roth (Public Health), Carrie Sanders (History), and Alexandra Verini (English). For a detailed discussion of their role as article contributors, see endnote 4 above. 